\title{
IMPACT OF MANAGERIAL ENTRENCHMENT AND GROUP AFFILIATION ON DIVIDEND POLICY IN EMERGING ECONOMY OF PAKISTAN EMPIRICAL EVIDENCE FROM KSE LISTED NON-FINANCIAL FIRMS
}

\author{
MUHAMMAD ANJUM FAREED \\ Pakistan Institute of Development Economics, Islamabad \\ ARSHAD HASSAN \\ Capital University of Science and Technology, Islamabad, Pakistan
}

\begin{abstract}
For analysis of managerial entrenchment hypothesis, insider's ownership (MSO) is divided into three parts, i.e., MSO less than $25 \%$, between $25 \%$ and $50 \%$ and above $50 \%$. For data analysis Random effect model and Tobit model are used. Many studies have shown the linear relationship among managerial ownership and firm's performance but a very few studies documented a non linear relationship in literature (Farinha, 2002; Chen et al., 2005). The study presented a non linear relationship between insiders' ownership and dividend policy, i.e. at low level $(\mathrm{MSO}<25 \%)$ a negative relationship exists which proves the agency theory hypothesis, whereas above this level (MSO>25\%) a significant positive relationship is documented which is backed by the managerial entrenchment hypothesis, as at high level of MSO "resource extraction" and above 50\% level "expropriation of minority rights" exist. Group affiliation (ASSO) is also included to see the impact on dividend policy and results reveal a significant negative relation between group affiliation and dividend policy.
\end{abstract}

\section{INTRODUCTION}

Dividend policy is one of the most controversial issues and highly researched area in corporate finance literature since Joint Stock Companies came into existence. Many researchers try to uncover the issues regarding the dividend behavior or dynamics and determinants of dividend policy but still no acceptable explanation for the observed dividend behavior of firms has been finalized (Black, 1976; Allen \& Michaely, 2003; Brealey \& Myers, 2003).

Research on dividend payout started by Lintner (1956) who argued that to maintain a long run payout ratio firms follow smooth dividend payments in United States. Subsequently, Miller and Modigliani (1961) and Black (1976) developed theory on dividend payout. Afterwards, financial specialists and economists have been working on this most controversial issue to solve the dividend puzzle over a half century but it is still an unresolved issue which needs further discussion. It is considered one of the issues that are still the subject of debate among both academics and practitioners. "The harder we look at the dividend picture, the more it seems like a puzzle, with pieces that don't fit together" (Black, 1976). As Black (1976) raises the question, "Why do firms pay dividends"? Further he raises a second question, "Why do investors pay attention to dividends?" Brealey and Myers (2005) stated that dividend policy is among one of the top ten key unsolved issues in financial economics.

There is a difference of objectives of corporate shareholders and mangers which is termed as Agency Conflict. Shareholders are the owners of firms and they demand a positive high return on their investment, while the managers have others goals, such as attaining power advantages and prestige of running a large organization, enjoying services (entertainment) and other perquisites of their position. In this situation, managers have superior access to inside information and powers of their position which means that mangers will have an upper hand and thus agency problem will arise between mangers and shareholders. Another important perspective in case of Pakistan that most of firms are owned by family investors, institutional investors or foreign investors that means having insider control or concentrated ownership structure. It generates a new agency conflict named as "expropriation of minority shareholders by majority shareholders" which exists among small shareholders 
and controlling (large) shareholders as they will affect the dividend or reward of small shareholders because controlling owners can confiscate the real information (value) from small shareholders (Javed \& Iqbal, 2010).

"Agency theory" which states that dividend is a source to reduce the costs arising due to managershareholder conflict of interest. Dividends also perform as a controlling function which monitors the activities of firm's management (Rozeff, 1982; Easterbrook, 1984; Jensen, 1976). Jensen (19s76) argues that firms which used to pay dividends regularly reduce extra funds available under managerial control and thus problem of investment in less profitable projects can be resolved. In corporate finance literature mitigating agency cost through dividend payout policy is recent development.

Corporate dividend policy seems to be effected by ownership structure of firms as it is considered as an important influencing variable. In Pakistan, ownership structure is opposite to dispersed ownership structure of Anglo- American as corporations are mostly owned by concentrated family ownership structure. Jensen and Meckling's (1976) work on corporate ownership literature highlighted the issue of separation of ownership control, which results the conflict among the shareholders (Principle) and managers (Agents). Jensen and Meckling (1976) argue that managerial share ownership in a firm helps to remove the agency problem and align the interests of shareholders (owners) and managers. There is an argument which exists that managers get entrenched when managerial share ownership crosses a high level and it results in agency problems (Demsetz, 1983; Fama and Jensen, 1983; Chen et al. 2005). Dividend is a voluntary payment in Pakistan and it needs to be explored thoroughly and this study focuses on the determinants of dividend policy with main focus on managerial ownership and group affiliation.

\section{LITERATURE REVIEW}

\section{Theoretical Review on Role of Corporate Governance and Dividend Policy}

Starting from most authenticated work of Lintner (1956) who developed a mathematical model to study how U.S. industrial firms make dividend decisions, based on survey study. He concluded that most important factors that influence the dividend payment pattern of firms are current year earnings and lagged year dividends. Miller \& Modigilani (1961) are two focal names when debate of dividend theories is discussed.
Miller and Modigliani (1961) presented "MM irrelevance theory" and assumed that dividend payments have no impact on firm's value by following perfect capital market conditions because shareholders are more concerned about the firm's investment polices as compared to dividends or capital gains. Before MM irrelevance theory, it was believed that dividend payments do matter and affect firm value. Dividend relevance theory is considered as "Bird in hand theory". Gordon and Walter (1963) explained the investor's preference towards cash in hand, due to uncertainty in world, because different stakeholders have imperfect information and to minimize the risk they avoid future promises of capital gain.

Corporate ownership literature got momentum from the influential work of Jensen and Meckling (1976). They presented the "Agency Theory" which is based on conflict of interest that arises due to separation of principle (e.g the shareholder/owners) and agent (e.g the management of company). This conflict of interest creates the high agency costs as different stakeholders are interested to maximize their own personal goals, even sometimes at other's expense. Shareholder's primary object is maximization of share value while managers have other goals, such as attaining an upper hand which offers a powerful position, entertainment, having superior access to inside information or some other perquisites. In this situation, managers (agents) may be involved in such actions which may be against the rights of principle (shareholders). The dilemma of asymmetric information may be another cause of agency conflict as all parties are involved in different information sharing.

Bhattacharya (1979) explained "Signaling theory" as this theory is based on information asymmetries and dividends can mitigate the information asymmetry between managers and shareholders and provide inside information of firm's future prospects to outsiders. Managers are responsible for dealing with firm's day to day operations and they have more complete information about real worth of firm than shareholders and this information may be shared to outsiders through following an appropriate dividend policy. Therefore, dividends can be used as a tool to convey information to market and to foster trust between shareholders and corporate managers through reducing information asymmetries.

The next theory is "Free cash flow theory" which is connected with agency theory. According to free cash flow theory, free cash flows refer to primarily amount that is left after investing in all projects having positive net present value and is available for shareholders as dividends distribution. Corporate managers are hired for smooth running of business so managers are supposed 
to work with a prime objective of maximization of shareholders' wealth. But sometimes, these managers are involved in inefficient utilization of funds through investing in negative NPV projects or prefer their own interest at shareholders' expense. Jensen (1986) related this hypothesis with agency theory and declared it as an overinvestment problem as adequate free cash flows don't always allow management to invest in positive NPV projects. He suggested the solution of overinvestment problem by reducing amount of free cash flows through distributing dividends to shareholders.

Miller and Scholes (1978) discussed the Tax preference theory, which states that investors set different portfolios in selection of dividend or capital gain due to different tax rates levied on dividends and capital gain. Dividends tax rates are high as compared to capital gain tax rate and dividend are taxed directly, on the other hand capital gains are taxed at the time of sale of stock and investors who don't sell their shares will pay capital gain tax in a year in which they sell out their shares. Therefore, investors don't prefer cash dividends due to tax related reasons.

\section{Review of Empirical Studies (International Evidence)}

For the past few decades, a number of theoretical models have been proposed by academicians and researchers to explain the determinants of dividend policy. Jensen (1986) argued based on the agency theory that the conflict of interest between managers (agents) and external shareholders (owners) can be reduced through distribution of dividends to shareholders as this will result in no expropriation of retained earnings by managers. Managers follow the growth opportunities and want to retain the profits instead of paying dividends. But shareholders want cash dividends instead of retained earnings. On the other hand, managers try to retain more profits to get much control over resources of organization. Thus, in case of low dividend payments more resources will accumulate and managers may use these resources for their personal well being or they may be involved with investing in unprofitable projects of negative NPV.

Jensen et al. (1992) used three stage least square (3SLS) to examine interdependence between the determinants of level of managerial ownership, dividend and leverage levels by using a cross- sectional firm data. They applied and split data into two segments of time, 565 firms for 1982 and 632 firms for 1987. They argued that insider ownership has significant affect on dividend policy and debt level of firms. Profitability was positively related with dividend payouts, while growth and investment opportunities have negative impact on dividend.

.In case of Jordanian economy Al-Malkawi (2007) studied the main inflectional factors of dividend policy of listed firms at Amman Stock Exchange (ASE) over a period of 1989 to 2000 . The findings of research showed that stocks held by insiders and government ownership has significant affect on dividend policy. $\mathrm{He}$ also argued that firm size, profitability and age are main influential factors for dividend decisions.

\section{Dividend Policy and Corporate Governance Practices in Pakistan}

In Pakistan, rights of minority share holders are exploited by majority shareholders. In business affairs, in case of any misconduct by other shareholders, only the shareholder having 20\% shareholding in company can go to a court and may ask for help. Furthermore, a shareholder having $10 \%$ shareholding can only file a complaint against the issue to SECP.

According to Ahmed \& Javid (2010) corporate investor ownership has a significant relationship with dividend growth in Pakistan. They used a sample of 50 KSE- 100 index non financial firms over a period of 2001 to 2006 to explain the firm's ownership structure and dividend payouts association. No significant link was observed between institutional ownership, director ownership and dividend payouts, but a positive relationship was found among sales and earnings growth with dividend payments.

Afza \& Mirza (2009) conducted a study in emerging market of Pakistan to find out the impact of institutional ownership i.e. insurance companies ownership, national investment trust ownership, mudarbah ownership and miscellaneous institutional ownership on dividend payout. They applied OLS technique for analysis of data. They found that growth opportunities and leverage are negatively related with dividend payouts and firm size and profitability are positively related with dividend payouts. Modarba ownership has no significant impact in determination of dividend policy as modarba business is not yet developed in Pakistan.

Shah Ullah and Hasnain (2011) carried out a research to determine the effect of ownership structure on dividend policy of listed firms at KSE. Using common effect model, they concluded that managerial ownership significantly affects the dividend policy. In case of high managerial ownership, corporate dividend payout is also high, while minority shareholders have no affect to change the dividend payout decisions of firms listed at KSE. Afza et al. (2010) explained that firms which have large board size pay high amount of dividends and also follow a regular dividend payout 
policy. No significant impact has been found between board independence and payout ratio. Mehar (2005) empirically explained that in Pakistan, firms make dividend payout decision after payments of taxes, thus dividend payout is less than that of other emerging markets and it is also argued that more often than not dividends are distributed to favor the managers rather than the shareholders.

Afzal and Sehrish (2011) investigated the impact of corporate governance practices and corporate dividend policy by examining a sample of $42 \mathrm{KSE}$ listed nonfinancial firms in Pakistan. Corporate dividend is used as dependent variable and ownership structure and board composition as independent variables. Using OLS regression, logit and probit models they concluded a significant positive relationship between individual ownership, board size, firm size and investment opportunities with dividend payouts. Profitability shows a positive relation with dividend payouts as they also found some stable companies which regularly distribute a specific portion of earnings as dividends.

\section{Insider Ownership (MSO)}

Insider ownership / managerial ownership is meant to be the sum of proportion of managers, executives, directors and their families divided by the total capital shares of the firm. These insiders are family owned firms or the majority shares held by the management. In review of different studies mixed results are found regarding insider ownership and dividend policy. Hussain and Saleem Ullah (2011) argue that as insider ownership increases, insider owners get more power and board control which results in high amount of dividend payments. This argument is termed a resource extraction hypothesis.

Whereas, other researchers argued that if insiders increase MSO in the firm, agency costs may be reduced as it will result in aligned interests as well as removal of interest conflicts among management and shareholders. Similarly, dividend-induced monitoring won't be needed, but because their larger stakes give them more power to retain profits inside the firm. In this case, to reduce the agency costs lesser funds would be sufficient for payment of high dividends (Jensen and Meckling, 1976; Jensen et al., 1992: Al-Malkawi, 2007). Thus, insider stock ownership and dividend policy are viewed as substitute means of addressing potential agency problem.

Hypothesis 1. All else equal, there is a significant relationship (positivel negative) influence of insider ownership on dividend payout.

\section{Managerial Entrenchment}

Empirical studies have shown that managerial ownership is not a linear function of agency costs. Shleifer and Vishny (1988) found that managerial ownership is related to company's performance in a nonlinear way so dividend policy may be affected accordingly. Farinha (2002) argued a U-shaped relationship between managerial ownership and dividend payout in the UK.

In equation (2), we allow for non-linearity in the relationship between corporate payout and ownership percentage of the controlling shareholder. For analysis of different insider's ownership we have divided our sample into three parts present MSO less than $25 \%$, between $25 \%$ and $50 \%$ and above $50 \%$. It is assumed at low level insiders, ownership an MSO and dividend policies are being used as substitute of corporate governance, so less will be needed for dividend payments.

On the other hand above a critical entrenchment level, dividend policy may play the role of a monitoring mechanism, mitigating entrenchment-related agency costs. Therefore, above the entrenchment level, a positive relation exists between dividend payout and insider ownership.

\section{Hypothesis 2. All else equal, there is a significant negative relationship between managerial ownership and dividend payments below an entrenchment level and positive relationship above that level.}

\section{Business Group Affiliation (ASSO)}

Pakistan is a developing country and high concentrated ownership exists in corporate environment. The "Business Groups" is a term used to describe the family owned and controlled firms as defined by Gani and Ashraf (2005). In an agency framework, a higher ownership percentage of group companies and group affiliation should reduce agency conflict between shareholders and managers. In this case, dividend policy may become less important as a monitoring tool.

\section{Hypothesis 3. All else equal, there is a negative influence of group affiliation (ASSO) on dividend payout.}

In this study 40 group businesses have been identified in Pakistan (See Appendix A). In our sample of 120 firms total 47 firms have been identified as group affiliated firms. List of sector wise affiliated firms is provided in data collection method. A dummy variable has been used in this study taking the value of 1 (one) if company is 
affiliated to a business group and zero (0) otherwise.

\section{Control Variables}

\section{Firm size}

Sajid et al. (2012) reported positive association between size and dividends of Pakistani firms. Large firms feature greater information asymmetry as a result of the dispersion of ownership. Thus, a large dividend payout ratio can be one solution for this problem. Thus, the following hypothesis is formulated in relation to firm size:

\section{Hypothesis 4. There is a positive relationship between firm size and dividend policy.}

\section{Leverage}

The level of financial leverage negatively affects the dividend policy of a firm. Al-Kuwari (2009) found that the leverage ratio is significantly and negatively associated with the dividend payout ratio. So following hypothesis is proposed:

Hypothesis 5. There is a negative relationship between firm financial leverage and dividend policy.

\section{Growth Opportunities}

According to La Porta et al. (2000), some firms have fewer growth opportunities but tend to pay higher dividends to prevent managers from over-investing the cash available to the firm. Sajid et al. (2012) found positive association between dividend payout ratios and growth. Hence, based on the previous discussion, our hypothesis is:

\section{Hypothesis 6. There is a positive relationship} between firms' growth and dividend policy.

\section{Profitability}

The decision to pay dividends starts with profits. Lintner (1956) found that a firm's net earnings are main determinants of dividend changes. Al-Kuwari (2009) found a statistically significant and positive relationship between profitability and the dividend payout ratio. Based on both theory and empirical evidence, the study hypothesizes is:

\section{RESEARCH METHODOLOGY}

This section provides the analytical framework for empirical testing of hypothesis formulated in section 3 and data used to test these hypotheses

\section{Methodological Framework}

To test the impact of ownership structure and corporate governance on the dividend policy of firms listed on Karachi Stock Exchange, two models are developed by following Al Kuwari (2009). In Model 1 we included group affiliation firm's control variables specially to analyze the impact of insiders' ownership. For analysis of different insider's ownership we have divided our sample into three parts present MSO less than $25 \%$, between $25 \%$ and $50 \%$ and above $50 \%$. Therefore, the two models are:

Model 1

$$
\mathrm{DIV}=\mathrm{f}(\mathrm{MSO}, \mathrm{ASSO}, \mathrm{SIZE}, \mathrm{LEV}, \mathrm{GROW}, \mathrm{PROF})
$$

\section{Empirical Specification of the Models}

In this equation (1), we analyzed the effect of various Insider ownership and group association on dividend policy. So, equation 1 is as follows:

$$
\begin{aligned}
& \operatorname{Div}_{(\mathrm{i}, \mathrm{t})}=\beta_{\mathrm{o}}+\beta_{1} \mathrm{MO}_{(\mathrm{i}, \mathrm{t})}+\beta_{2} \mathrm{FS}_{(\mathrm{i}, \mathrm{t})}+\beta_{3} \mathrm{LEV}_{(\mathrm{i}, \mathrm{t})}+\beta_{4} \mathrm{GROW}_{(\mathrm{i}, \mathrm{t})} \\
& +\beta_{5} \operatorname{ROA}_{(\mathrm{i}, \mathrm{t})}+\beta_{6} \mathrm{ASSO}_{(\mathrm{i}, \mathrm{t})}+u_{(\mathrm{i}, \mathrm{t})} \ldots \ldots .(1)
\end{aligned}
$$

\section{Managerial Entrenchment and Dividend Policy}

In this equation (2) analysis explain the effect of various levels of Insider ownership dividend policy. So, equation 2 is as follows:

$$
\begin{aligned}
& \operatorname{Div}_{(\mathrm{i}, \mathrm{t})}=\beta_{\mathrm{o}}+\beta_{1} \mathrm{MO}_{(\mathrm{i}, \mathrm{t})}+\beta_{2} \mathrm{MO}_{(\mathrm{i}, \mathrm{t})}+\beta_{3} \mathrm{MO}_{(\mathrm{i}, \mathrm{t})}+\beta_{4} \mathrm{ASSO}_{(\mathrm{i}, \mathrm{t})}+ \\
& \beta_{5} \mathrm{FS}_{(\mathrm{i}, \mathrm{t})}+\beta_{6} \mathrm{LEV}_{(\mathrm{i}, \mathrm{t})}+\beta_{7} \mathrm{GROW}_{(\mathrm{i}, \mathrm{t})}+\beta_{8} \mathrm{ROA}_{(\mathrm{i}, \mathrm{t})}+u_{(\mathrm{i}, \mathrm{t})} \ldots \ldots . .(2) \\
& \beta=\text { Coefficient (Parameter) } \\
& \mathrm{u}(\mathrm{i}, \mathrm{t})=\text { Error Term }
\end{aligned}
$$

\section{Technique of Estimation}

This study covers the data of 125 firms for the period of eleven years; therefore it is appropriate to use panel data estimation technique. In panel data, observations on different cross-sectional units over several time periods are pooled together, which allows to increase the sample size and increasing the degrees of freedom.

This study used static analysis i.e. fixed effect model and random effect models. Housman specification test is 
applied to check whether FEM or REM provide correct specifications under null hypothesis, that individual effect are uncorrelated with other regressors' in model. So if the null hypothesis is rejected then FEM is preferred otherwise REM.

In case of Pakistan, many companies do not pay dividend at all, and even those who pay dividend may have negative income in any time period so there will be negative dividend payouts which makes no sense. Therefore OLS estimates of coefficients might be inconsistent and biased towards zero (AlMalkawi, 2007). To handle this issue, present study has used Tobit model which is supported by existing financial researchers Maddala (1992) because the dividend distribution is censored from below at zero.

\section{Data Collection Source and Sample Selection}

To explore the relationship of ownership structure, board characteristics on dividend policy, the study used the data of 125 non- financial listed firms at Karachi Stock Exchange. The data set of study is derived from annual reports of companies listed at Karachi Stock Exchange and Balance Sheet Analysis of KSE published by State Bank of Pakistan of manufacturing sector (non-financial firms) over a period 11 years covering 2003 to 2013. Firms of different ownership structure are included in this study. Data of ownership variables were collected manually from annul reports of listed companies. Data includes various sub sectors of the manufacturing sector of Pakistan which consists of Textile, Cement, Telecommunication, Paper Board, Food, Chemicals, Paper, and Motor Vehicles etc. The analysis and data collection are started from 2003 because data of detailed ownership structure was reported first time in 2003 after implementation of Code of Corporate Governance 2002.

Summarizing data for this research have been collected from two sources:

i) Annual reports of the listed companies

ii) Balance Sheet analysis of non-financial companies listed at KSE issued by State Bank of Pakistan

\section{Major Business Groups in Pakistan}

In this study 40 group businesses have been identified in Pakistan (See Appendix A). In our sample of 125 firms, total 47 firms have been identified as group affiliated firms which include as follows
Major Business Groups in Pakistan

\begin{tabular}{|c|c|c|}
\hline Sr. No & Name & $\begin{array}{l}\text { No. of } \\
\text { Firms }\end{array}$ \\
\hline $\begin{array}{l}\text { Sector } \\
\text { No. } 1\end{array}$ & $\begin{array}{l}\text { Textile: Spinning, Weaving, } \\
\text { Finishing of Textile }\end{array}$ & 17 \\
\hline $\begin{array}{l}\text { Sector } \\
\text { No. } 2\end{array}$ & Food Products sector & 7 \\
\hline $\begin{array}{l}\text { Sector } \\
\text { No. } 3\end{array}$ & $\begin{array}{l}\text { Chemicals, Chemical Products \& } \\
\text { Pharmaceuticals }\end{array}$ & 4 \\
\hline $\begin{array}{l}\text { Sector } \\
\text { No. } 4\end{array}$ & Manufacturing sector & 9 \\
\hline $\begin{array}{l}\text { Sector } \\
\text { No. } 5\end{array}$ & $\begin{array}{l}\text { Motor Vehicles, Trailers } \\
\text { \&Autoparts }\end{array}$ & 5 \\
\hline $\begin{array}{l}\text { Sector } \\
\text { No. } 6\end{array}$ & Electrical Machinery \& Apparatus & 3 \\
\hline $\begin{array}{l}\text { Sector } \\
\text { No. } 7\end{array}$ & Misc. sector (other services) & 2 \\
\hline
\end{tabular}

\section{Variable Description \& Construction}

Based on different empirical studies we have selected a number of variables that may influence the dividend payout policy.

\section{i. Measurement of Dependent Variable}

A firm can retain or distribute its earnings among shareholders; however it should use the decision that maximizes its market value. We have used two dependent variables to answer the research questions. In this study, a dividend per share is used to measure the dividends behavior of a firm. Dividend payout is used as a proxy for dividend policy, as different researchers have used this proxy to explain the dividend policy (Ahmed \&Attiya, 2009: Al-Malkawi, 2007).

Dividend Per Share $=$ Total Amount of Dividend $/$ Total Outstanding Shares

Dividend payout Ratio $=$ Dividend per Share $/$ Earnings per Share.

\section{ii. Measurement for Independent Variables}

\section{Insider ownership:}

Insider ownership is calculated as percentage shares held by managers, executives, board of directors, and their families including spouse and minor child to total number of shares outstanding (Rozeff, 1982; AlMalkawi, 2007).

Insider ownership (MSO) $=$ Total shares held by directors and CEOs, and families / Total no. of shares 


\section{Insider ownership: Different Levels}

Insider ownership is calculated as percentage shares held by managers, executives, board of directors, and their families including spouse and minor child to total number of shares outstanding (Rozeff, 1982; AlMalkawi, 2007).To check the Insiders' Entrenchment, whole sample is divided into three parts

Insider ownership (MSO) $=$ Total shares held by directors and CEOs, and families / Total no. of shares i.e. MSO less than $25 \%$, between $25 \%$ and $50 \%$ and above $50 \%$.

\section{Control Variables}

\section{Size of the firm}

The size has been taken as a control variable and measured in terms of assets by taking the log of total assets.

Size of Firm (FS) = Natural log of Total Assets

\section{Growth of the firm}

Growth of the firm is another important determinant of dividend payout policy and it is calculated as market to book ratio.

\section{Leverage}

Growth $($ GROW $)=$ Market to Book ratio

Leverage is used as a control variable and calculated by ratio of total liabilities to total assets Al-Kuwari (2009).

\section{Leverage $($ LEV $)=$ Total liabilities/ Total Assets}

\section{Profitability}

It is an important explanatory variable of dividend policy Al-Kuwari (2009).

Profitability $(\mathrm{ROA})=$ Profit after depreciation, interest and tax / Total Assets

\section{Group Affiliation}

Dummy Variable Group affiliation " 1 " if a firm is affiliated with a major business group, "0" otherwise

\section{RESULTS AND DISCUSSION}

This section presents the empirical results. Regression results of different models are examined using data of 125 non-financial firms for the period of nine years: 2003 to 2013 .

\section{Descriptive Statistics}

TABLE 1

Descriptive statistics

\begin{tabular}{lccccc}
\hline Variables & Mean & Median & Max & Min & $\begin{array}{l}\text { Std. } \\
\text { Dev. }\end{array}$ \\
\hline \multicolumn{7}{c}{ Dependent Variables } \\
\hline $\begin{array}{l}\text { Dividend per } \\
\text { share }\end{array}$ & 0.488 & 0.100 & 17.498 & 0.000 & 1.250 \\
$\begin{array}{l}\text { Dividend } \\
\text { Payout Ratio }\end{array}$ & 0.242 & 0.115 & 5.790 & -5.650 & 0.564 \\
\hline \multicolumn{7}{c}{ Firm characteristics } \\
\hline $\begin{array}{l}\text { Firm Size } \\
\text { Leverage }\end{array}$ & 3.537 & 3.558 & 5.617 & 0.708 & 0.724 \\
$\begin{array}{l}\text { Growth } \\
\text { Return on }\end{array}$ & 14.567 & 1.340 & 331.480 & -115.080 & 24.753 \\
assets & 0.080 & 0.064 & 2.052 & -6.830 & 0.242 \\
\hline \multicolumn{7}{c}{707.884} & 0.040 & 47.864 \\
\hline $\begin{array}{l}\text { Insider } \\
\text { ownership }\end{array}$ & 0.275 & 0.250 & 0.900 & 0.000 & 0.224 \\
$\begin{array}{l}\text { Group } \\
\text { Affiliation }\end{array}$ & 0.400 & 0.000 & 1.000 & 0.490 & 0.247 \\
\hline
\end{tabular}

The descriptive stats of dependent variable with all of the explanatory variables have been performed for the period of 2003 to 2011 on the sample of 100 non financial manufacturing firms of Pakistan listed at KSE.

Table 1 shows the means, medians, standard deviations; maximum and minimum values of our key variables of combined sample of study (125 firms). The mean value of dividend paid per share is 0.48 and the median is o.10. The maximum amount of dividend per share is 17.49 . The mean value of dividend payout ratio (DPR) is 0.24 which is lower as compared to developed countries. On the other hand, profitability and growth are on higher side relative to dividend yield indicating that firms earning more have the ability to pay more in the form of dividend payout but firms are not inclined to make dividend payments indicated by lower actual dividend yield. An additional striking result is higher leverage ratio. Debt to equity ratio is on average 3.46 indicating total debt is 3.46 times of total equity i.e. almost 3.5 times of equity indicting that Pakistani manufacturing firms rely heavily on debt rather than equity. This may be the reason of not making dividend payments. Even then firms rely heavily on debt financing rather than equity means a higher retention of earnings by management reflecting that managers retain earnings to maintain their business liquidity requirements. Insider ownership is on average 0.27 and maximum 0.90 , whereas, group affiliation is 0.40 on average. 


\section{Correlation Matrix}

The correlation matrix shows the relationship between the dependent and explanatory variables. The results obtained in this study are reported in Table 2 from the correlation matrix are as follows: The primary purpose of correlation analysis is to identify potential determinants of dividend payout policy. Secondly, it is also meant to detect multicolinearity in the data. It indicates the absence of multicolinearity problem due to the low or moderate degree of correlation between the independent variables.

\section{Firm Specific Determinants of Dividend Policy}

The results show that dividend per share has a positive and significant relation with return on assets, firm size and growth opportunities and negative relationship with leverage. As, the dividend per share has positive and significant relation to the size of the firms $(0.25)$ indicating that the size of the firm has a positive impact on dividend yield. The dividend per share has positive but non-significant relation with leverage $(0.003)$. In case of investment opportunities and profitability, the dividend per share has positive and significant relation with new investment opportunities (0.78) and return on investment $(0.21)$. MSO is found to have negative correlation with dividend payout and dividend per share in Pakistan. The negative correlation between MSO and dividend proxy in Pakistan is in line with the existing empirical evidences reported by Afza and Mirza (2010). Group affiliation is also negative with dividend policy

\section{Results of REM \& Tobit model}

Table 3 presents the results of two estimation techniques for the dividend payout policies, using Equation (1) for Random effects Model in first column the haussman Test shows $\mathrm{P}$ value at 0.12 , which shows the acceptance of REM over the FEM among the Panel data estimations. The model shows the adjusted $\mathrm{R}^{2}$ at 0.54 which means $54 \%$ of dependent variable part is being explained by the independent variables.

Column 4 of table 3 shows the results of equation (1) for tobit model. This model is used because of the issue that dividend payouts could not be negative, these may be positive or zero. So, tobit model is better choice as this makes the data censored from below at zero. The results are in line with random effect model estimations.

\section{Control Variables and Dividend Policy Results}

The results in Tables 3 and table 4 show that there is a significant and positive relationship between firm size and dividend payment decision, at the $99 \%$ confidence interval. This result is in line with previous studies, that larger firms are capable of paying larger dividends (Jensen et al., 1992; Al- Malkawi 2005). Another explanation for this positive association might be related to large firms' easier access to capital markets, and their ability to raise funds with lower issuance costs for external financing.

The relationship with leverage is significantly negative in equation 1 and 2 so that companies with high debt will least likely be involved in paying dividends (Jensen et al. 1992), which is in line with the agency theory of debt. This means that if the leverage ratio of a firm is increased, the dividend payout ratio paid by the firm decreases. The reason for this negative association is that highly leveraged firms carry a large burden of transaction costs from external financing. In this case, firms need to maintain their internal source of funds to meet their duties, instead of distributing the available cash to shareholders as dividends (Al-Malkawi, 2005).

TABLE 2

Correlation between Firm Specific Variables and Dividend yields

\begin{tabular}{lllllllll}
\hline Correlation & DPS & DPO & FS & LEV & MBR & ROA & MSO & ASSO \\
\hline Dividend per share & 1.00 & & & & & & & \\
Dividend Payout & 0.28 & 1.00 & & & & & & \\
Firm Size & 0.25 & 0.13 & 1.00 & & & & & \\
Leverage & 0.003 & 0.00 & 0.02 & 1.00 & & & & \\
Growth & 0.78 & 0.15 & 0.18 & 0.01 & 1.00 & & & \\
Return on assets & 0.21 & 0.13 & 0.14 & 0.00 & 0.15 & 1.00 & & \\
Insider ownership & -0.07 & 0.04 & -0.20 & 0.07 & -0.12 & -0.10 & 1.00 & \\
Group Association & -0.09 & -0.14 & 0.06 & 0.06 & -0.04 & -0.16 & -0.13 & 1.00 \\
\hline
\end{tabular}


TABLE 3

Managerial Ownership, Group Association and Dividend Policy

\begin{tabular}{lcccc}
\hline Variables & \multicolumn{2}{c}{ Equation } & \multicolumn{2}{c}{ TOBIT DPO } \\
& Coefficient & T value & Coefficient & T value \\
\hline Constant & $-0.373^{* *}$ & --2.45 & -0.083 & -0.969 \\
Firm Size & $0.158^{* * *}$ & 3.983 & $0.086^{* * *}$ & 3.734 \\
Leverage & $-9.94 \mathrm{E}-05$ & -0.117 & $-5.47 \mathrm{E}-05$ & -0.061 \\
Growth & $0.014^{* * *}$ & 34.213 & $0.001^{* * *}$ & 3.982 \\
Return on assets & $0.139^{* *}$ & 2.500 & $0.161^{* * *}$ & 2.662 \\
MSO & 0.090 & 0.705 & $0.148^{* * *}$ & 2.297 \\
ASSO & -0.100 & -1.322 & $-0.126^{* * *}$ & -3.974 \\
Adjusted R-squared & 0.540762 & & & \\
D - W stat & 0.94 & & & \\
F-statistic & 213.7383 & & & \\
Prob(F-statistic) & 0 & & & \\
Hausman Test & 0.12 & & 1.47771 & 125 \\
Akaike info criterion & & & 1375 & \\
No. of Firms & 125 & 1375 & & \\
No. of Observations & & & & \\
\hline
\end{tabular}

***,**. and * denote significance at 1 percent, 5 percent, and 10 percent respectively

The estimated coefficient for growth opportunities shows the significant positive relation between dividend payout and dividend per share and it is also significant at $95 \%$ confidence interval as $\mathrm{p}$ value is less than 0.05 and t value is 3.98. These results are consistent with $\mathrm{La}$ Porta et al. (2000), who had argued that in countries with low legal protection for investors, dividend payouts are high in order to establish a strong reputation and to get better investment opportunities. Some firms have fewer growth opportunities but tend to pay higher dividends to prevent managers from over-investing the cash available to the firm (Sajid et al., 2012). Thus payment of dividends will help in mitigating the agency cost of free cash flow.

In this study ROA has a significant positive relationship with dividend policy and results show the positive relation at $95 \%$ confidence interval. This seems more logical because companies which earn more profits would be more willing to pay dividends. This result is in line with the signaling theory of the dividend policy. Therefore, the more profitable the firm is, the higher the possibility to pay dividends (Al-Kuwari, 2009; Amidu et al., 2006).

Results of REM and Tobit model show a positive and significant association between managerial ownership and dividend policy, which shows that agency theory hypothesis, does not hold. Group affiliation of companies shows a negative association with dividend policy which means agency theory hypothesis holds and less information asymmetry exists.

\section{Managerial Entrenchment and Dividend Policy Results}

In table 4, equation (2) is estimated and we presented results for both random effect model and tobit model to show the different levels of insiders' ownership and its impact on dividend policy effects; the results have been shown in three different columns in order to analyze the individual effect of each insiders' ownership level.

The results of table 4 show that large insider controlling shareholders (ownership percentage above $25 \%$ ) are successful in extracting relatively large resources from the company through dividend payments and this relationship is significant at $95 \%$ confidence interval with a t- value 2.65; which is in line with the resource extraction argument. There is also a significantly negative relationship between dividend payout and controlling shareholder's ownership below $25 \%$. These results indicate that below an entrenchment level insider ownership and dividend policies are being used as substitute corporate governance devices, therefore, leading to a negative relationship between these two variables and hence, dividend policy may become less important as a monitoring tool.

These findings are in the line with those documented by Chen et al. (2005) who found a negative relation between dividend payouts and family ownership up to $10 \%$ of the company's stock and a positive relationship for ownership in the 10 to $35 \%$ range for a sample of publicly listed, small market capitalization firms. 
TABLE 4

Managerial Entrenchment

\begin{tabular}{|c|c|c|c|c|c|c|}
\hline \multirow[t]{3}{*}{ Variables } & \multicolumn{6}{|c|}{ Equation 3 (4.3.3) } \\
\hline & REM & TOBIT & REM & TOBIT & REM & TOBIT \\
\hline & DPS & DPO & DPS & DPO & DPS & DPO \\
\hline \multirow[t]{2}{*}{ Constant } & $-3.23 * * *$ & $0.27 * * *$ & -2.52 & $-0.45^{* *}$ & $-2.38 * *$ & $1.26 * * *$ \\
\hline & -6.502 & 3.049 & -3.212 & -2.176 & -1.757 & 3.879 \\
\hline \multirow[t]{2}{*}{ Firm Size } & $0.497 * * *$ & 0.003 & 0.030 & $0.085^{*}$ & 0.480 & $-0.145^{* * *}$ \\
\hline & 4.128 & 0.143 & 0.181 & 1.738 & 1.617 & -2.272 \\
\hline \multirow[t]{2}{*}{ Leverage } & $-0.200 * * *$ & 0.002 & -0.094 & -0.001 & $-0.176^{*}$ & 0.001 \\
\hline & -2.895 & 1.356 & -1.293 & -0.465 & -1.928 & 1.121 \\
\hline \multirow{2}{*}{ Growth } & $0.010 * *$ & $0.001 * * *$ & $0.06 * * *$ & $0.007 * *$ & $0.111 * * *$ & 0.004 \\
\hline & 2.245 & 3.863 & 5.823 & 2.176 & 3.804 & 0.941 \\
\hline \multirow{2}{*}{ Return on assets } & $4.651 * * *$ & $0.656^{* * *}$ & $5.168 * * *$ & $0.295^{*}$ & 0.638 & 0.026 \\
\hline & 6.578 & 5.769 & 4.140 & 1.646 & 0.762 & 0.368 \\
\hline \multirow[t]{2}{*}{$\mathrm{MSO}<25 \%$} & -0.425 & $-0.639 * * *$ & & & & \\
\hline & -0.305 & -2.780 & & & & \\
\hline \multirow[t]{2}{*}{$\mathrm{MO}>25 \%<50 \%$} & & & 1.140 & $1.008 * * *$ & & \\
\hline & & & 0.881 & 2.653 & & \\
\hline \multirow[t]{2}{*}{$\mathrm{MO}>50 \%$} & & & & & -1.478 & $-0.752 * * *$ \\
\hline & & & & & -1.565 & -2.704 \\
\hline \multirow[t]{2}{*}{ ASSO } & 0.099 & $-0.186^{* * *}$ & 0.297 & $-0.153 * * *$ & $-0.630^{*}$ & $-0.209 * * *$ \\
\hline & 0.654 & -5.564 & 1.583 & -2.718 & -1.943 & -2.762 \\
\hline Adjusted R-sq & 0.31 & & 0.34 & & 0.32 & \\
\hline D - W stat & 0.97 & & 1.15 & & 0.91 & \\
\hline F-statistic & 22.03 & & 13.18 & & 8.14 & \\
\hline Prob(F-stat) & 0 & & 0 & & 0.0 & \\
\hline Hausman Test & 0.10 & & 0.10 & & 0.10 & \\
\hline AIC & & 0.89 & & 1.28 & & 1.48 \\
\hline No. of Firms & & 125 & 125 & 125 & 125 & 125 \\
\hline No. of Observations & 1375 & 1375 & 1375 & 1375 & 1375 & 1375 \\
\hline
\end{tabular}

***,**. and $*$ denote significance at 1 percent, 5 percent, and 10 percent respectively.

They are also in line with the finding of Farinha (2002) that, above a critical entrenchment level estimated in the region of $30 \%$, the coefficient of ownership by management changes from negative to positive.

\section{CONCLUSION AND IMPLICATIONS}

The dividend policy remains to be a puzzle, even though many studies have proposed to explain why companies pay dividend. This paper aimed to examine dividend policy in an emerging market where insiders' ownership exists and minority shareholders' expropriation exists.

Dividend policy is significantly and positively related with board size, audit quality, firm size, growth opportunities; profitability is documented and empirically tested; whereas, dividend payout is significantly negatively related with leverage. The study also presented a non linear relationship between insiders' ownership and dividend policy as at low level $(\mathrm{MSO}<25 \%)$ a negative relationship exists which proves the agency theory hypothesis, whereas above this level (MSO $>25 \%$ ) a significant relationship is documented. This hypothesis is backed by the managerial entrenchment hypothesis as at high level of MSO "resource extraction" and "expropriation of minority rights" exist. Group affiliation (ASSO) is also included to see the impact on dividend policy and results revealed a significant negative relation with group affiliation and dividend policy. The investment opportunities have significantly positive relationship with the dividend payout and negative relationship is being observed with leverage. The insider's ownership (CEO shareholdings and directors' shareholdings) has positive and significant relation with dividend payouts.

In case of Pakistan where majority insiders control 
exists, the presence of independent directors could be effective because their presence can ensure that the interest of minority shareholders. To improve the protection of minority shareholder, the role of auditors can further be enhanced by making the audit committee of the company more effective. Ultimately, dividend payments are voluntary in Pakistan so Securities and Exchange Commission of Pakistan (SECP) should impose a specific percentage of firm's net earnings, meaning that SECP should be involved in corporate affairs regarding dividend policy.

\section{LIMITATIONS \& FUTURE RESEARCH}

The study faced the problem of availability of data on ownership variables in Pakistan. Because of lack of specific organized or formal database, which could provide such data of non financial firms listed at Karachi Stock Exchange. So, we have manually collected ownership data from annual reports and websites of every listed company

After reading existing literature, one can understand the complexity of dividend puzzle. We recommend that institutional investors should be focused of future studies especially in case of Pakistan because almost all studies consider institutional ownership as homogeneous and only one study according to our knowledge is conducted by Afza \&Mirza (2011). So, it is important to analyze the presence of different types of institutional investors in the corporate ownership and their preferences for the dividend payments. Institutional investors may be banks, modarba companies, insurance companies or mutual funds etc and their preferences for dividend income should be examined.

\section{REFERENCES}

Afza,T. \& Mirza, H.H., 2010. Ownership Structure \& Cash flows as determinants of corporate Governance and Capital Structure: Evidence from Tehran Stock Exchange. Middle-East Journal of Scientific Research, 11(4), 531-535.

Afzal, Sehrish. (2011). Ownership Structure, Board Composition, and Dividend Policy in Pakistan African Journal of Business Management, 7(11), pp. 811-817

Ahmed, H. and J. Attiya. (2009). Dynamics and Determinants of Dividend Policy in Pakistan (Evidence from Karachi Stock Exchange Non Financial Firms), International Journal of Finance and Economics, Issue 25, 148-171.

Al-Kuwari. (2009). Determinants of dividend policy of companies listed in Emerging Stock Exchanges: The case of the Gulf Corporation Council (GCC)
Countries. Global Economy and Finance Journal, 2(2), 36-63.

Allen \&Michaely.(2003). Payout policy.Handbook of Economics of Finance, 1(a), 337-429.

Al-Malkawi. (2007). Determinants of corporate dividend policy in Jordan: an application of the Tobit model. Journal of Economics and Administrative Sciences. 23(2), 44-70.

Amidu, M., \& Abor, J. (2006). Determinants of dividend payout ratios in Ghana. The Journal of Risk Finance, 7(2), 136-145.

Bhattacharya, S. (1979), "Imperfect Information, Dividend Policy and "the Bird in the Hand" Fallacy, The Bell Journal of Economics, 10(1), 259-270.

Black, F. (1976), "The Dividend Puzzle", Journal of Portfolio Management, Vol. 2, pp. 5-8

Black, F. and Scholes, M. (1974) The effects of dividend yield and dividend policy on common stock prices and returns, Journal of Financial Economics, 1(1), $1-22$.

Brealey, R. A., Myers, S. C., 2003. Principles of Corporate Finance, 7th edition. McGraw Hill, New York.

Chen, M. (2005) Group affiliation, identity of managers, and the relation between managerial ownership and performance, International Review of Financial Analysis, 14(5), 535-558.

Demsetz, H., and K. Lehn. 1985. The Structure of Corporate Ownership: Causes and Consequences. Journal of Political Economy 93(6), 1155-1177.

Easterbrook, F. H. (1984). Two agency-cost explanations of dividends. The American Economic Review, 74(4), 650-659.

Fama, and Jensen. (1983). Separation of Ownership and Control. Journal of Law and Economics, 26(2), 301-325

Farinha, J.(2003). Dividend policy, corporate governance and the managerial entrenchment hypothesis: an empirical analysis. Journal of Business Finance \& Accounting, 30(9-10), 1173-1209.

Gani, W. I. and J. Ashraf (2005). Corporate Governance, Business Group Affiliation and Firm Performance: Descriptive Evidence from Pakistan. Lahore University of Management Sciences. (CMER Working Paper No 05-35).

Gordon MJ (1963). "Optimal Investment and Financing Policy” J. Finan.18 (2):264-72

Iqbal, J., Brooks, R., \& Galagedera, D. U. (2010). Testing conditional asset pricing models: An emerging market perspective. Journal of International Money and Finance, 29(5), 897-918.

Jensen Et al., (1992 1992), "Simultaneous Determination of Insider Ownership, Debt, and Dividend Policies", The Journal of Financial and Quantitative Analysis, 
27(2), 247-263.

Jensen M, Meckling W (1976). Theory of the firm: Managerial behavior, agency costs and ownership structure. J. Financ. Econ. 3, 305-360.

Jensen, G. R., Solberg, D. P. and Zorn, T. S. (1992), "Simultaneous Determination of Insider Ownership, Debt, and Dividend Policies", The Journal of Financial and Quantitative Analysis, 27(2), 247263.

Jensen, M. C. (1986). Agency cost of free cash flow, corporate finance, and takeovers. Corporate Finance, and Takeovers. American Economic Review, 76(2).

Kim, B., and G. Maddala (1992), "Estimation and Specification Analysis of Models of Dividend Behavior Based on Censored Panel Data," Empirical Economics 17, 111-124.

La Porta, Silians, Shleifer\&Vishny. (2000). Investor protection and Corporate Governance. Journal of Financial Economics, 58(1), 3-27.

Lintner.(1956). Distribution of Incomes of Corporations among Dividends, Retained Earnings, and Taxes. The American Economic Review, 46(2), May. pp.
97-113

Maddala, G. S., \& Lahiri, K. (1992). Introduction to econometrics (Vol. 2). New York: Macmillan.

Mehar (2005).Corporate Governance and Dividend Policy. Pakistan Economic and Social Review, pp.93-106.

Miller, M. H., \& Modigliani, F. (1961). Dividend policy, growth, and the valuation of shares. The Journal of Business, 34(4), 411-433.

Miller, M. H., \& Scholes, M. S. (1978). Dividends and taxes. Journal of Financial Economics, 6(4), 333364.

Morck, R., Shleifer, A., \& Vishny, R. W. (1988). Management ownership and market valuation: An empirical analysis. Journal of Financial Economics, 20, 293-315.

Rozeff, M. S. (1982). Growth, beta and agency costs as determinants of dividend payout ratios. Journal of financial Research, 5(3), 249-259.

Shah, A. Z., \& Wasim, U. (2011). Impact of ownership sturcture on dividend policy of firm. In International Conference on E-Business, management \& economics. IPEDR. Hong Kong.

APPENDIX \# 1

Major Business Groups in Pakistan

\begin{tabular}{|l|l|l|l|}
\hline 1 & NISHAT GROUP & 21 & IBRAHIM GROUP \\
\hline 2 & THE SAIGOLS GROUP & 22 & UNITED GROUP \\
\hline 3 & CRESCENT GROUP & 23 & (SADIQSONS) OF COMPANIES \\
\hline 4 & DEWAN GROUP & 24 & BAWANY GROUP \\
\hline 5 & THE HOUSE OF ITTEFAQ & 25 & SCHON GROUP \\
\hline 6 & CHAKWAL GROUP & 26 & DADA BHOY GROUP \\
\hline 7 & SAPHIRE/ GULISTAN & 27 & RUPALI GROUP \\
\hline 8 & HABIB GROUP & 28 & SITARA GROUP \\
\hline 9 & GUL AHMAD / AL-KARAM & 29 & COLONY GROUP \\
\hline 10 & PACKAGES GROUP & 30 & PREMIER GROUP \\
\hline 11 & ATLAS GROUP & 31 & SHAHNAWAZ GROUP \\
\hline 12 & HASHWANI GROUP & 32 & FAZAL GROUP \\
\hline 13 & BIBOJEE GROUP & 33 & SITARA GROUP \\
\hline 14 & DAWOOD GROUP & 34 & UMER GROUP \\
\hline 15 & MONNOO GROUP & 35 & CALICO GROUP \\
\hline 16 & FECTO GROUP & 36 & ADAMJEE GROUP \\
\hline 17 & LAKHANI (LAKSON) & 37 & TAWAKKAL GROUP \\
\hline 18 & SARGODHA GROUP & 38 & JEHANGIR ELAHI GROUP \\
\hline 19 & ALNOOR GROUP & 399 & KASSIM DADA GROUP \\
\hline 20 & GHULAM FAROOQ & 40 & KOHISTAN GROUP \\
\hline
\end{tabular}

